\title{
Politik som organiserad kamp - nya spelare och nya spelregler i Sverige
}

\author{
Stefan Svallfors
}

SAMMANDRAG: Stefan Svallfors artikel utgår från Jacob Hacker och Paul Piersons iakttagelse, i deras Winner-take-all politics (20IO), att politik först och främst är organisation, närmare bestämt "organiserad kamp". Perspektivet betyder att vi, för att förstå politikens utfall, måste studera hur den är organiserad i ett längre perspektiv - av vem och med vilka resurser? Svallfors visar att den svenska organiserade politiken har förändrats i grunden under de senaste årtiondena, en utveckling som inte har fått den uppmärksamhet den förtjänar. Det handlar bland annat om nedmonteringen av den korporativistiska ordningen, ett förändrat ramverk för ekonomiskt-politiskt beslutsfattande, en mer ojämlik inkomstfördelning, försvagade politiska partier och förändringar i partiernas sociala bas, ett minskat inflytande för fackföreningarna, framväxten av en ny grupp professionella politiska aktörer, ett större behov av att bedriva politiskt arbete på flera nivåer samt en starkare koppling mellan politik och medier. I artikeln diskuterar Svallfors hur denna utveckling har påverkat dagens politiska landskap och lett till en för Sverige ny form av elitdrivet "politikskapande".

NYCKELORD: politik som organisation; "organiserad kamp"; den svenska modellen; välfärdsstat; korporativism; politikskapande; politiska institutioner; policyprofessionella; ojämlikhet.

PUbLICERINGSHistorik: Originalpublicering. Artikeln är en översättning av manus skrivet på engelska.

STEFAN SVALLFORS är professor i sociologi vid Umeå universitet, gästprofessor vid Institutet för social forskning vid Stockholms universitet samt affilierad forskare vid Institutet för framtidsstudier i Stockholm.

E-POSTADREss: stefan.svallfors@soc.umu.se

FÖRSLAG PÅ KÄLLANGIVELSE:

Svallfors, Stefan (20I4) "Politik som organiserad kamp - nya spelare och nya spelregler i Sverige", i Arkiv. Tidskrift för sambällsanalys, nr 3, s. 39-64. DOI: http://dx.doi.org/IO.I3068/2000-6217.3.2

(C) Stefan Svallfors/Arkiv förlag \& tidskrift 2014 (publicerad 22 december 20I4)

Artikeln distribueras enligt en upphovsrättslicens från Creative Commons: Erkännande-Ickekommersiell-IngaBearbetningar 3.0 Unported, som medger fri ickekommersiell användning och spridning i oförändrat skick så länge källan anges. 
Arkiv. Tidskrift för samhällsanalys är en sakkunniggranskad vetenskaplig tidskrift för samhällsvetenskap och historia. Samtliga artiklar publiceras fritt tillgängliga på:

www.tidskriftenarkiv.se

(beständig länk, DoI: http://dx.doi.org/IO.I3068/2000-62I7)

Den här artikeln finns tillgänglig i följande format:

PDF \& HTML: via beständig länk, DOI: http://dx.doi.org/IO.I3068/2000-62I7.3.2 EPUB: ingår i e-boksutgåva av numret, ISBN: 978 9I 79242657

TRYCK: ingår i bokutgåva av numret, ISBN: 978 9I 79242664

Grafisk utformning och sidnumrering är identisk i pdf och tryck.

Samtliga artiklar i nr 3 (20I4) nås via beständig länk, DOI: http://dx.doi.org/I0.13068/2000-6217.3

Arkiv. Tidskrift för sambällsanalys ISSN: 2000-62I7 (för elektronisk resurs)

ISSN: 2000-6225 (för tryckta nummer)

ges ut av

Stiftelsen Arkiv för främjande och spridning av samhällsvetenskaplig och historisk forskning

genom

Arkiv förlag \& tidskrift

Box 1559

SE-22I OI Lund

ВESÖK: L Gråbrödersg 3 c, ipg

TEL: O46-I3 3920

ARKIV FÖRLAG: arkiv@arkiv.nu·www.arkiv.nu

TIDSKRIFTEN ARKIV: red@tidskriftenarkiv.se · www.tidskriftenarkiv.se

ANSVARIg UTGIVARE \& CHEFREDAKTÖR: Sven Hort

ADMINistrativ RedAKTÖr: David Lindberg

ReDAKTörer: Paavo Bergman, Lisa Kings, Zhanna Kravchenko 


\title{
Politik som organiserad kamp - nya spelare och nya spelregler i Sverige
}

\author{
STEFAN SVALLFORS
}

Denna artikel tar avstamp i Jacob Hackers och Paul Piersons iakttagelse, i deras Winner-take-all Politics, att politik först och främst är organisation eller rent av "organiserad kamp" (Hacker \& Pierson 20IO, s. IOO-IO2). För att förstå politikens processer och utfall räcker det inte att studera de senaste valen, hävdar de. De är inget annat än "politik som skådespel för väljarna”. I stället måste vi ta reda på hur politiken är organiserad i ett längre perspektiv - av vem och med vilka resurser? Och vi måste lyfta fram politikens utfall: det som regeringen faktiskt gör och som påverkar samhället. Hacker och Pierson nämner ett antal förändringar av politikens organisation och innehåll under de senaste årtiondena som på ett dramatiskt sätt har ökat ojämlikheten i USA. De sammanfattar sin syn på politiken som organiserad kamp så här:

När vi väl inser att det är politikens utfall och inte valsegern som är förstapriset i den politiska konflikten ser vi politiken för vad den är: en tävling där mycket står på spel, ofta för lång tid framåt - en tävling som mer liknar gladiatorspelen i Roms Colosseum än matcherna mellan Celtics och Lakers i Staples Center. Och

Artikeln bygger delvis på forskning som finansierats av Vetenskapsrådet (42I-20II1369) och är en översättning av ett originalmanus skrivet på engelska. Tack till Daniel Naurin och Henrik Oscarsson för värdefull assistans och till Pepper Culpepper, Jonathan Hopkin, Sven Hort, Kerstin Jacobsson, Julie Lynch, Bo Rothstein, Niels Selling, Michael Shalev, Sven Steinmo och Wolfgang Streeck för kritiska, uppmuntrande och användbara kommentarer. 
vilka är de tävlande? Vilka är de politiska gladiatorerna? Till allra största delen inte de atomiserade väljarna. De viktigaste kombattanterna, de som står kvar i ringen från början till slut, höjer sina vapen och parerar varandras slag, är de organiserade grupperna. (Hacker \& Pierson 20IO, s. IO2)

I artikeln används Sverige som exempel på hur politiken som organiserad kamp har förändrats ganska dramatiskt under det senaste kvartsseklet. Till skillnad från Hacker och Pierson är avsikten här inte i första hand att förklara förändringar i inkomstfördelningen. I stället använder jag deras bild av politiken som organiserad kamp som utgångspunkt för att belysa politisk-organisatoriska förändringar i ett samhälle som skiljer sig starkt från det amerikanska. Jag kommer visserligen med några välgrundade spekulationer om hur förändringarna är kopplade till förändringar i inkomstfördelningen, men fokus ligger på de politisk-organisatoriska förändringarna i sig och inte på deras inverkan på inkomstfördelningen.

Sverige kommer att tjäna som exempel av flera skäl: det är det land som författaren råkar känna till bäst, det framhålls ofta som en motsats till USA bland de rika kapitalistiska länderna, men det har på senare år genomgått ett antal ganska radikala politiska förändringar som inte har fått den uppmärksamhet de förtjänar. Om Sverige en gång sågs som mönsterexemplet för organiserad kapitalism och som ett mer eller mindre permanent fäste för socialdemokratin, har landet på senare tid genomgått så stora förändringar av den organiserade politiken och "politikskapandet” att det nu är dags att ifrågasätta gamla etiketter.

Förändringarnas konsekvenser verkar till stor del ha underskattats av både utländska och inhemska observatörer, kanske för att de nästan enbart har intresserat sig för partiernas och väljarnas arena. Och där verkade Moderaternas erkännande av bärande inslag i den svenska modellen och välfärdsstaten signalera den slutgiltiga segern för en omfattande och omfördelande välfärdsstat (Steinmo 20Io, kap. 2; Svallfors 20II; Lindbom [kommande]). De som med stöd av detta hävdar att den svenska ekonomisk-politiska modellen alltjämt lever ser de Nya Moderaterna som bärare av en gammal svensk förmåga att kombinera en jämlik och långtgående välfärdspolitik med ekonomisk konkurrenskraft (Steinmo 2013).

Men som jag vill visa med den här artikeln har bredare och starkare politiska och sociala strömningar verkat under valmaskineriets yta. De 
krafterna tycks peka mot en ny politisk maktordning i Sverige, vars konturer i stora drag kan anas men vars konkreta innehåll ännu inte låter sig bestämmas.

\section{Den organiserade politikens förändring - Sveriges förändring}

Sveriges organiserade politik har förändrats ganska genomgripande på senare år, som när det gäller det institutionella ramverket, politikens och valens sociala bas och de sätt på vilka politikens processer och innehåll är organiserade.

Först och främst har den formella korporativistiska modellen till stor del monterats ner (Hermansson m.fl. 1999; Lindvall \& Sebring 2005). Arbetsgivarnas utträde ur alla statliga korporativistiska styrelser 1991 fick till följd att även fackföreningarna uteslöts. Centrala löneförhandlingar mellan Svenska Arbetsgivareföreningen och LO hade upphört redan på I980-talet. Korporativismen - med dess formella och starkt synliga form av utomparlamentariskt politiskt beslutsfattande - har lämnat plats för mer informella och nätverksbaserade former av politiskt inflytande och kommunikation (post-korporativism), men vi vet ännu mycket lite om hur dessa fungerar och vad de får för konsekvenser.

Dessutom har det politiska ramverket förändrats på väsentliga punkter genom införandet av nya penningpolitiska regelverk och nya former av självpåtagna begränsningar, både i den ekonomiska och sociala sfären (Lewin \& Lindwall [kommande]). Sverige har nu en oberoende centralbank, en flytande växelkurs, budgetregler som är inriktade mot mål på medellång och lång sikt och en oberoende riksrevision. Pensionssystemet innehåller en automatisk "broms" som styrs av en algoritm (Lundberg 2003; 2009). De här institutionella förändringarna har i grunden begränsat den ekonomiska och sociala politikens manöverutrymme. De har också inneburit att viktiga beslut har förts över till instanser som inte är folkvalda och som erbjuder föga insyn.

När det gäller politikens sociala bas har den ekonomiska och sociala ojämlikhetens struktur förändrats radikalt (Björklund \& Jäntti 2oII; 20I3). Inkomstskillnaderna har ökat dramatiskt (OECD 20II), arbetslös- 
heten har stigit, atypiska arbeten har blivit vanligare, andelen utlandsfödda har ökat, utbildningsnivån har ökat - kort sagt har de sociala ojämlikheterna förändrats markant. Även om vi ännu vet rätt lite om hur förändringarna påverkar den politiska makten, och även om det saknas en fullständig bild av deras konsekvenser för det politiska deltagandet och politikens möjligheter, måste en så drastisk ökning av de ekonomiska ojämlikheterna som den i Sverige få politiska återverkningar.

Valmanskårens sammansättning är därför radikalt annorlunda jämfört med på 1980-talet och dess rörlighet har förändrat det politiska landskapet. Valdeltagandet sjönk från 1970- och 1980-talens höga nivåer (då det brukade ligga på över 90 procent) fram till år 2002 (cirka 80 procent), men har sedan 2006 ökat igen (Persson m.fl. 2013). Deltagandet har dessutom fătt en tydligare social koppling, eftersom den mest dramatiska nedgången har skett bland arbetare, lågutbildade och låginkomsttagare (Oscarsson \& Holmberg 2013, tabell 3.2).

Om vi i stället vänder blicken mot de politiska partierna så har dessa blivit märkbart svagare som arenor för politikskapande. Detta syns tydligast i den stora nedgången i partiernas medlemstal och i det faktum att partimedlemmarna blir alltmer olika "medelsvensson" (van Biezen m.fl. 20I2). Men det avspeglas också i väljarnas allt svagare identifiering med ett parti och i en nedgång i partiernas förmåga att ställa upp långsiktiga mål (Lindvall \& Rothstein 2006; Mair 2008). Partipolitiken har blivit mer reaktiv och tar till sig idéer och lösningar som ofta formuleras på andra arenor än partierna. Partierna har en benägenhet att förvandlas till "tomma kärl", som organiserade grupper ibland lyckas fylla med ett oväntat innehåll.'

Det finns i dag åtta riksdagspartier i stället för som tidigare fem, däribland extremhögern. Socialdemokraterna är inte längre det klart domi-

I. Det kanske mest slående exemplet är Centerpartiets fullständiga förvandling, en gång ett parti för jordbrukare och landsbygden, men nu Sveriges mest marknadsliberala parti, som uttalat sig för ytterligare avreglering av arbetsmarknaden, fri invandring och en tolerant hållning till droger och månggifte. Denna förändring drevs till stor del på av politiker och andra politiska aktörer med starka band till marknadsliberala tankesmedjor som Timbro (Bengtsson 2013; Nycander 2013). Experimentet har inte riktigt gått hem hos väljarna, för partiet lyckades skrämma bort stora delar av sin gamla, rätt konservativa väljarbas utan att få verkligt fäste hos de mer liberala, urbana väljarna (Uvell 2013). 
nerande partiet utan har utmanats i sin roll som det "naturliga styrande partiet" av de framryckande Moderaterna. Blockpolitiken har stärkts och i de tre senaste valen har en koalition bestående av fyra höger- och mittenpartier ställts mot ett mer lösligt format "röd-grönt" alternativ. Samtidigt har den idépolitiska skillnaden mellan partierna minskat, först till följd av Socialdemokraternas långsamma men stadiga drift mot mitten och från några år in på 2000-talet av Moderaternas tvära sväng mot mitten. Både vänsterns och högerns ideologiska positioner har alltså förskjutits radikalt, vilket har skapat nya politiska lojaliteter och nya ideologiska besvikelser (Blyth \& Katz 2005; Oscarsson \& Holmberg 2013).

Bland intresseorganisationerna har arbetarnas fackföreningar kraftigt försvagats. Det gäller både deras inflytande över politiken och deras medlemsantal. Nedgången speglar i viss mån den stigande arbetslösheten och de allt osäkrare anställningsförhållandena, men också strukturella förändringar på arbetsmarknaden, till exempel utvecklingen mot färre arbetare och fler tjänstemän. Men nedgången är också en följd av den förda politiken, såtillvida att differentierade och höjda avgifter till a-kassan efter 2006 har fått många unga arbetare att gå ur facket eller avstå från att gå med. Även om a-kassan formellt sett inte är kopplad till medlemskap i en fackförening har a-kassans pengar administrerats av fackföreningarna och underlättat medlemsrekryteringen. Genom att göra medlemskapet mycket dyrare har politiken försvagat LO (samtidigt som fackföreningarna fătt beröm för att vara en självklar och positiv del av den svenska modellen för tillväxt och omfördelning). Viktiga grupper på arbetsmarknaden, bland annat en stor del av arbetskraften inom servicesektorn, är inte fackanslutna över huvud taget.

Arbetarfackens minskade inflytande har ingen motsvarighet hos tjänstemannafacken. Deras ställning har tvärtom stärkts på senare år och detsamma gäller fackföreningar som i huvudsak organiserar grupper med akademisk utbildning (Kjellberg 20ıа; 20IIb). Förändringen i styrkeförhållandena mellan arbetar- och tjänstemannafack har alltså varit betydande. Detta är viktigt, eftersom tjänstemannafacken är mycket mindre intresserade av frågor som rör ojämlikhet och omfördelning än vad arbetarfacken är. Många av deras medlemmar är höginkomsttagare med trygga arbeten och kan förväntas ha ett svagare intresse för jämlikhets- 
främjande politiska åtgärder och reformer, medan många andra medlemmar är i samma sits som arbetarna i de här frågorna.

En annan viktig förändring i Sveriges organiserade politiska verklighet är uppsvinget för en kategori som vi skulle kunna kalla "policyprofessionella” (jfr Heclo I978). Det rör sig om personer som är avlönade för att påverka den politiska processen och politikens innehåll utan att vara förtroendevalda. De återfinns både innanför och utanför riksdagen och partipolitiken. Hit hör grupper som politiskt sakkunniga, politiska sekreterare, experter inom fackföreningar och branschorganisationer, lobbyister, anställda på tankesmedjor med flera. De här personerna har ökat dramatiskt i antal under de senaste årtiondena och har antagligen fått ökat inflytande. Men mycket lite är alltjämt känt om vilka de är, vad de har för bakgrund och framtidsutsikter, vilken roll de spelar i den politiska processen och vad som driver dem (Garsten m.fl. [kommande]). Det är emellertid helt klart att pr-byråerna, som i praktiken inte spelade någon roll alls inom svensk politik fram till mitten av I990-talet, nu intar en central plats i det politiska landskapet. De fungerar som en sorts börser för politiskt kapital, där kunskaper som förvärvats inom politiken kan bytas mot penningbelöningar i form av högre löner eller utdelningar. De fungerar också som resursbaser och dörröppnare för de klienter som har råd att betala deras arvoden för att komma i åtnjutande av deras politiska kunnande och information.

Även om det är svårt att i dag säga särskilt mycket om vilket inflytande den mycket heterogena gruppen policyprofessionella faktiskt har, är det uppenbart att de ägnar sig åt politik mer eller mindre i det fördolda. Deras politiska arbete försiggår under såväl mediernas som den statsvetenskapliga forskningens radar. Den senare har alltjämt en benägenhet att koncentrera sig på de folkvalda politikerna och den offentliga administrationen. För att utöva politiskt inflytande förenar de policyprofessionella kunskap och makt genom att nätverka och utnyttja andra sociala och kognitiva resurser. Ändå är detta en i hög grad osynlig form av maktutövning (jfr Culpepper 20II).

Svensk politik blir alltmer ett spel på flera nivåer. Internationella överenskommelser får ökad betydelse, vilket kommer till tydligast uttryck i och genom Europeiska unionen. Sverige har delegerat och överlåtit 
mycket makt till EU och måste följa dess närmast federala juridiska system. EU:s politikskapande processer är väldigt svårgenomträngliga och komplexa, vilket ger initierade personer en enorm fördel när det gäller att påverka beslut och utfall. Detta gör också att lobbyföretag och intresseorganisationer dras till EU:s arena och andra multilaterala miljöer för att kunna påverka besluten innan de senare återimporteras till Sverige som lagar och rekommendationer (Naurin 2007).

Konsekvenserna av juridikens intrång på politikens arena - som har varit en viktig del av den europeiska integrationen - har varit mer dramatiska i Sverige än på andra håll. För det första har fokuseringen på individens rättigheter haft en liberaliserande verkan. Trycket på medlemsstaterna att avreglera, liberalisera och öppna sina nationella välfärdssystem för andra EU-medborgare har inneburit en stor utmaning för de mest reglerade sociala marknadsekonomierna (Scharpf 20ı0; Höpner \& Schäfer 20I2). För det andra ingår i den svenska demokratiska traditionen ingen juridisk granskning eller stark roll för domstolarna på det politiska området, vilket däremot är fallet i andra sociala marknadsekonomier som Österrike och Tyskland. De svenska politiska aktörerna är därför inte vana vid att ha domstolar som motpart och att ta rättslig strid för en sak.

Den svenska välfärden har genomgått en omfattande privatisering och styrningen av den offentliga sektorn har gått mot fler marknadsbaserade lösningar och olika former av "new public management" (Blomqvist 2004; Bergh \& Erlingsson 2009; Gingrich 20II). Även om praktiskt taget all utbildning, vård och omsorg i Sverige fortfarande betalas med skattemedel har sättet på vilket tjänsterna tillhandahålls förändrats ganska dramatiskt sedan 1990-talet. I dag svarar icke-offentliga operatörer för en betydande del av vården och omsorgen (cirka $15-20$ procent med små variationer mellan olika verksamhetsområden, men med större variationer mellan olika kommuner och landsting) (Hartman 2oıı; Jordahl 2013).

När vården och omsorgen öppnades för den privata sektorn utgjordes till en början en betydande del av de icke-offentliga operatörerna av kooperativ och andra icke vinstdrivande operatörer. $\mathrm{Nu}$ för tiden är majoriteten av de privata operatörerna vinstdrivande, i de flesta fall stora 
aktiebolag eller riskkapitalbolag som i en del fall inte ens har sitt säte i Sverige. Konsekvenserna av reformerna i termer av effektivitet och ändamålsenlighet är omstridda (Hartman 20II). Det råder dock inget tvivel om att de har förändrat välfärdsstatens organisation på ett genomgripande sätt och gett upphov till nya former av byråkratiska arbetssätt och nya yrkesroller och användarupplevelser inom välfärdssektorn (Jordahl 2013). Det är också tydligt att framväxten av det som en journalist har kallat "det välfärdsindustriella komplexet" har format ett inflytelserikt maktblock inom svensk politik. Tack vare sina egna ekonomiska resurser och via sin viktigaste branschorganisation har dessa välfärdsindustriella företag nu en stark röst i frågor om välfärdsstatens finansiering och organisation (Blomqvist 2004, s. I52).

Sist men inte minst har politiken blivit kopplad till medierna på ett ganska dramatiskt sätt (Strömbäck 2008; Esser 2013). I dag bedrivs politik via massmedierna dygnet runt sju dagar i veckan. Nästan konstant medieuppmärksamhet har blivit ett villkor för politisk överlevnad i en process där politikens förpackning och mediespridning är det viktigaste. Det politiska ledarskapet anpassar sin stil efter förändringar i mediediskursen och politiskt ansvar utkrävs ofta i medierna (Ekström \& Tolson 2013).

\section{En ny politisk ordning}

Förändringarna i den sociala basen, institutionerna och organisationsformerna har påverkat de befintliga politiska aktörernas manöverutrymme och gett möjlighet åt nya spelare att göra sig gällande. Förändringarna har dessutom på olika sätt påverkat både politikens inre funktionssätt och villkoren för de politiska åtgärdernas verkställighet. Mer eller mindre samma förändringar märks i en rad andra avancerade demokratiska kapitalistiska samhällen - men det finns skäl att tro att de har haft mer dramatiska konsekvenser i Sverige än på andra håll. Det beror till stor del på att det svenska utgångsläget skilde sig från det i många andra rika länder: en större välfärdsstat, en starkare socialdemokrati, mindre juridisk granskning, starkare organisationer, mer utvecklade korporativistiska institutioner och mer offentligt reglerade massmedier. Men det 
är dessutom så att den svenska utvecklingen i vissa avseenden varit snabbare och mer genomgripande än i jämförbara länder. Till exempel har den kraftiga ökningen av vinstdrivande välfärdsföretag inte haft någon motsvarighet i andra koordinerade marknadsekonomier. Och de ökade inkomstskillnader som noterats på senare år har förändrats snabbare i Sverige än i andra nordiska och nordvästeuropeiska länder (OECD 20II).

Ändå vet vi påfallande lite om hur förändringarna har påverkat maktförhållandena. I de andra nordiska länderna Danmark, Finland och Norge tillsattes omfattande utredningar och forskningsprogram under I990- och 2000-talen med uppgift att studera grundläggande frågor om den politiska makten (Østerud m.fl. 2003; Togeby m.fl. 2003). ${ }^{2}$ Inget liknande har genomförts i Sverige sedan den senaste maktutredningen avlade sin slutrapport 1990 (Maktutredningen 1990). Bland de förändringar som jag har räknat upp är det troligt att några driver de andra, att en del trender är närmare knutna till varandra än andra och att åter andra är viktigare än de övriga. Än så länge står vi emellertid på för osäker empirisk grund för att kunna säga något säkert om orsakerna till de trender vi ser.

Även om det ännu inte forskats tillräckligt för att man ska kunna dra en säker slutsats om den nya politiska ordningens följder för den politiska makten i Sverige, är det på sin plats med några preliminära iakttagelser. Hit hör den förändrade aktörsuppsättningen inom politiken och politikskapandet, den minskade synligheten och allt större otydligheten i politiken, förhållandena mellan den ekonomiska och den politiska makten och slutligen den självförstärkande dynamiken mellan ojämlikhet, delaktighet, maktresurser och politikens utfall.

För att förstå hur mycket aktörsuppsättningen har förändrats inom svensk politik kan vi gå tillbaka till I980-talet och studera vilka som då var de viktigaste organiserade politiska aktörerna och vad som kännetecknade dem. Sverige hade förstås fortfarande det starkaste socialdemokratiska partiet i världen, ett parti som kunde räkna med över 40 procent

2. Finlands Akademis forskningsprogram "Makt i Finland" (2007-20IO) redovisas på http://www.aka.fi/sv/A/Program-och-samverkan/Akademiprogram/Avslutade/Makt-iFinland/, hämtat I2 december 2014 . 
av rösterna i val efter val och som sällan varit borta från regeringsmakten sedan 1930-talet. Nära lierat med det partiet ända sedan dess tillkomst i slutet av I80o-talet var ett starkt och centraliserat LO. Mer löst kopplade till denna maktaxel återfanns en rad organisationer som representerade pensionärer, hyresgäster och andra grupper med socialdemokratiska värderingar (Olofsson 1995).

Det största tjänstemannafacket, TCO, kunde också betraktas som en del av denna socialdemokratiska koalition av löntagare. TCO var visserligen mycket mer fristående från Socialdemokraterna än vad LO var, men även denna organisation hade samma grundläggande värderingar och synsätt som den organiserade arbetarrörelsen (Nilsson 1985).

De viktigaste motparterna och motståndarna återfanns dels i en lös koalition av höger- och mittenpartier. Dessa hade sällan lyckats bilda en samlad front och deras relativa valframgångar hade växlat från val till val. Deras korta perioder vid makten hade slutat med regeringskriser. Men den viktigaste aktören på politikens och maktens marknadsliberala högersida fanns inte bland de politiska partierna. Det var i stället en resursstark, mycket centraliserad och alltmer stridslysten arbetsgivarförening. Svenska arbetsgivare och i synnerhet storskaliga kapitalägare hade alltid, vilket man ska komma ihåg, varit en viktig del av den svenska modellen (Fulcher 199I). Efter en lång period av fördragsamhet gentemot de socialdemokratiska makthavarna kom arbetsgivarna och deras organisation på 1970-talet och framåt att inta en aggressivare attityd mot vad de uppfattade som överdrivna och ekonomiskt skadliga omfördelningar och skattenivåer. Särskilt negativ var man till de långtgående förslagen om att utvidga det offentliga kapitalägandet via löntagarfonder (Boréus 1994).

Aktörsuppsättningen vid den här tiden bestod alltså av folkvalda politiker, företrädare för organisationer och offentliga administratörer. De var uppbundna i allehanda korporativistiska strukturer och överenskommelser, de var internt starkt centraliserade och de hade alltjämt näst intill monopol på det tillgängliga politiska handlingsutrymmet.

Dagens situation är radikalt annorlunda. Som påpekades ovan har den korporativistiska ordningen monterats ner och de gamla politiska aktörerna har på olika sätt försvagats, även om de alltjämt är i hög grad 
närvarande. I stället har vi fått flera nya organiserade deltagare i det politiska maktspelet, bland annat (a) de policyprofessionella som omtalades ovan, vilka arbetar för sina egna organisationer (till exempel politiska partier) eller på uppdrag av betalande klienter; (b) storföretag med direkt intresse i välfärdsstaten och politikens framtida inriktning; (c) tankesmedjor och andra organiserade producenter av politiska idéer. Detta innebär också en förskjutning från det som ytterst sett är demokratiskt styrda organisationer till organisationer som mer bygger på politiskt specialistarbete och monetära resurser.

Vad den nya aktörsuppsättningen innebär i makthänseende syns kanske tydligast i välfärdsbranschen, som numera är ordnad som ett antal marknader och pseudomarknader, där storföretag har blivit tunga spelare. ${ }^{3}$ Socialdemokraternas märkliga ovilja att ta itu med de problem som förknippas med de vinstdrivande företagens aktiviteter inom vård- och skolsektorerna vittnar om partiets rädsla för att utmana denna resursstarka grupp politiska aktörer. Trots att en stor majoritet av svenskarna säger sig vara skeptiska till vinstdrivande verksamheter inom skattefinansierad vård och omsorg (Nilsson 2013) har Socialdemokraterna varit ytterst försiktiga med att föreslå begränsningar i vinstuttaget och andra regleringar av branschen.

Skiftet i aktörsuppsättningen har åtföljts av en minskad synlighet vad gäller de politiska processerna. Det gäller särskilt den "genomströmning" ("throughput") som Schmidt ser som ett viktigt tillägg till den traditionella distinktionen mellan politikens "input-" och "outputfaser". Begreppet "genomströmning" syftar på de olika styrprocesser genom vilka demokratisk input omvandlas till politisk output (Schmidt 2013).

3. En indirekt men ändå rätt talande indikation på detta är att 2013 var det första året som Investor, Wallenbergsfärens viktigaste investmentbolag, fanns på plats under den årliga Almedalsveckan i början av juli, då politiker, andra politiskt verksamma och massmedier träffas i Visby. Wallenbergfamiljen är fortfarande den överlägset största kapitalägaren i Sverige och håller vanligen en låg profil. Deras plötsliga uppdykande för att göra sin röst hörd i Almedalen var antagligen en följd av att de gett sig in i den vinstdrivna välfärdsbranschen och därmed hade ett direkt intresse i hur den offentliga politiken utformades. Att detta var något mer än ett plötsligt infall att delta i den offentliga debatten bevisas av att Investor (och andra stora kapitalplacerare med intressen i välfärdssektorn) på senare tid har försökt påverka LO:s ståndpunkt när det gäller vinster i välfärden (Öberg 20I4). 
Genomströmningsstadiet påverkas av maktrelationerna mellan olika myndigheter, av samarbeten och konflikter mellan offentliga och privata aktörer i målformuleringen samt av inre maktkamper i de politiska partierna, myndigheterna och de utförande organisationerna. Makt handlar i det här stadiet om att utforma och omvandla politiska förslag till ett politiskt innehåll.

Flera av de utvecklingstrender som nämndes i förra avsnittet bidrar till den minskade synligheten i det här stadiet av den politiska processen. De policyprofessionellas verksamhet är ett exempel. Deras arbete som rådgivare, spinndoktorer och producenter och spridare av politiska idéer är ganska osynligt för den stora allmänheten (och till och med för de flesta lärare i statsvetenskap!). De gynnas av komplexiteten och skyr rampljuset för egen del, men använder samtidigt massmedierna som huvudarena för att påverka politiken och politikutformningen. Detta förklarar varför de policyprofessionella och politikens medialisering är så nära förbundna med varandra. Befogenheter och ansvar blir otydliga, inte minst i relation till de folkvalda politikerna (Garsten m.fl. [kommande], kap. 4; jfr Heclo I978 och Hermansson m.fl. 1999).

En annan orsak till politikens minskade synlighet ligger i det faktum att politik som förs på flera nivåer är komplex och svårgenomtränglig. Detta har skapat utmärkta möjligheter för inhemska politiska aktörer att föra en "skuldundvikandets politik" (Weaver 1986; Svallfors 2000, kap. 5). Framför allt genom att "lägga skulden på EU" för impopulära beslut och vägval har politiker i en del fall lyckats gå fria från skuld (men samtidigt minskat legitimiteten för EU) (Kumlin 2009). Ur medborgarnas perspektiv kan sådana uppvisningar i "skuldundvikande" inte annat än öka förvirringen när det gäller vem som bör hyllas eller klandras för de politiska besluten.

En annan kännbar konsekvens av den europeiska integrationen som också påverkar politikens synlighet är politikens överföring till det rättsliga området. Det är självklart att juridikens ökade inflytande gör politiken mindre tillgänglig. Detta kallas ibland "lagens mask", vilket syftar på att politiska frågor döljs bakom ett juridiskt språk som bara juridiskt skolade begriper (Burley \& Mattli 1993). Även för utbildade samhällsoch statsvetare är den juridiska jargongen svårgenomtränglig, liksom för 
fackföreningsaktivister och politiker. I ett land med så svag tradition av att blanda in juridiken i politiken är det troligt att den ökade svårtillgängligheten blir särskilt kännbar.

Det är alltså en formlös och ogenomskinlig politisk maktordning som nu reser sig ur ruinerna av det gamla korporativistiska socialdemokratiska bygget. I denna maktordning har dessutom styrkeförhållandena mellan den ekonomiska och den politiska makten förskjutits påtagligt.

Kapitalet har förstås alltid och i ökad omfattning haft en strukturell och indirekt politisk fördel gentemot arbetskraften, såtillvida att det är lättare att mobilisera och flytta (Culpepper 20II; Streeck 20I3). Men nu tillkommer pengarnas direkta inflytande i form av nya möjligheter att helt enkelt köpa de bästa politiska råden och åtgärderna från policyprofessionella (som pr-konsulter) vars betydande kunskaper är till salu på marknaden. Även om pr-byråernas tjänster, liksom kunnandet hos de policyprofessionella i allmänhet, i princip kan köpas av var och en som har råd understryker de här gruppernas uppkomst och tillväxt ytterligare de ekonomiska resursernas betydelse för den som vill påverka politikens riktning. ${ }^{4}$

I frågor som rör välfärdspolitiken har större privata företag - som redan påpekats - numera både ett direkt inflytande över och intresse i hur vården och skolan organiseras. Detta innebär att kapitalistiska företag direkt påverkar debatten och politiken på området, bland annat genom tjänsteföretagens viktigaste branschorganisation (Almega) och den viktigaste ägarsfären i Sverige, familjen Wallenberg och deras främsta investmentbolag Investor. Detta har utan tvivel rubbat balansen mellan den ekonomiska och den politiska makten ytterligare, eftersom

4. Sverige hör till de väldigt fă länder i Europa som saknar varje form av lagstiftning ifråga om ekonomiska bidrag till politiska partier. Partierna i riksdagen behöver inte ens berätta vilka deras största bidragsgivare är. Inte heller finns någon lagstiftning när det gäller svängdörrarna mellan politiken, näringslivet och lobbyföretagen. Ledande politiker och andra politikskapare kan gå direkt från politiska nyckelpositioner till lobbyverksamhet inom samma politiska område. Och pr-byråerna avslöjar sällan vilka storföretag de har som kunder. Sådana problem, som i praktiken gränsar till korruption, har diskuterats mycket i Sverige på senare år. Lagstiftningen släpar dock efter, framför allt för att Moderaterna har varit envisa motståndare till krav på öppen redovisning av partibidrag (som de hävdar skulle utgöra ett hot mot yttrandefriheten och valhemligheten). 
privata vårdgivare knappast fanns i Sverige förr och starka kapitalintressen inte hade något direkt intresse $\mathrm{i}$ hur välfärdspolitiken utformades och upprätthölls. ${ }^{5}$

Slutligen, vad har den här utvecklingen med den stigande inkomstojämlikheten i Sverige att göra? Detta är fortfarande oklart, men jag skulle vilja hävda att vi har fått en självförstärkande dynamik där ökande klyftor i inkomst- och välståndsfördelning leder till större skillnader mellan olika grupper vad gäller deras politiska deltagande och politiska resurser. Detta påverkar i sin tur utrymmet för politiska åtgärder i syfte att förändra eller bevara inkomstfördelningen.

Som påpekats har inkomstojämlikheterna ökat markant i Sverige på senare årtionden. Efter en lång period av solidarisk lönepolitik, omfördelningar via välfärdsstatens skatter och transfereringar samt stagnerande aktiemarknader var den svenska ojämlikheten som lägst i början av 1980-talet. Sedan dess har inkomstojämlikheten ökat kontinuerligt, av olika skäl under olika tidsperioder. Den individuella lönespridningen har visserligen ökat kraftigt (Korpi \& Tåhlin 20II) men sammantaget har denna delvis motverkats av förändringar i hushållens arbetstid, vilket innebär att spridningen på arbetsinkomsterna på hushållsnivå är något men inte dramatiskt större i dag än för trettio år sedan (Björklund \& Jäntti 20II, kap. 2).

I stället har den viktigaste faktorn bakom inkomstojämlikheten från början av 1990-talet och framåt varit kapitalinkomsternas storlek och spridning, framför allt kapitalvinsternas (Björklund \& Jäntti 20II, kap. 2; Roine \& Waldenström 20I2). Sådana förändringar har påverkat de allra flesta svenskar väldigt lite, men de har betytt mycket för den översta percentilen av inkomstfördelningen (Roine \& Waldenström 20I2, s. 577). Detta förklarar varför den svenska ojämlikhetsökningen har samma märkligt oproportionerliga form som den amerikanska, om än inte lika uttalat. Från 2006 och framåt har ökningen av kapitalvin-

5. Naturligtvis har svenskt kapital, liksom kapital överallt, alltid haft ett indirekt intresse i välfärdsstaten, eftersom löneskatter och andra direkta och indirekta kostnader för företagen behövde vara låga nog för att företagen skulle vara konkurrenskraftiga. Men detta var en annan sorts intresse jämfört med dagens direkta inblandning i utbudet av välfärdstjänster. 
sterna stagnerat, vilket med all sannolikhet mest beror på finanskrisen. I dag verkar i stället skattelättnader för breda lager av medelklassen i kombination med neddragningar i socialförsäkringssystemen vara den viktigaste faktorn bakom den ökade ojämlikheten.

Det ska sägas att långt ifrån alla förändringar i inkomstfördelningen är direkta följder av politiska beslut ${ }^{6}$ men många är det. När man diskuterar politikens betydelse för förändringarna $\mathrm{i}$ inkomstfördelningen är det viktigt att inte stirra sig blind på skatterna och transfereringarna - dessa är förstås viktiga men inte de enda faktorer som måste vägas in. Som Hacker och Pierson påpekar måste vi välja ett brett perspektiv och ta med alla slags lagar, förordningar och regleringar som påverkar inkomstfördelningen. Och här är den senaste tidens utveckling i Sverige ett talande exempel.

Den mest framträdande politiska åtgärden som påverkade inkomstfördelningen var den borgerliga regeringens skatteavdrag för personer i arbete ("jobbskatteavdrag") i kombination med sänkta ersättningar och kortare ersättningsperioder för arbetslösa och sjukskrivna. De reformerna infördes stegvis åren 2007 till 2013. Målet med skattesänkningarna var (sades det åtminstone) att sänka arbetslösheten och öka utbudet av arbetskraft genom att göra det mer intressant för arbetslösa och personer utanför arbetsmarknaden att ta ett arbete. Men efter krisen 2008 har ingen tydlig inverkan på sysselsättningen kunnat märkas. Det innebär att nettoeffekten av reformerna helt enkelt är en omfördelning från personer med låg inkomst från socialförsäkringssystemet till personer med löneinkomster - i absoluta tal har de allra högsta skattesänkningarna gått till personer i relativt höga inkomstskikt. I kombination med avskaffandet av arvsskatten (2005), förmögenhetsskatten (2007) och fastighetsskatten (2008) har Sverige på det här sättet fått ett klart mindre omfördelande skatte- och utgiftssystem.

Förändringarna i den förda politiken har dock bara påverkat inkomstfördelningen under de senaste åren och de har inte riktats mot den viktigaste orsaken till en mer ojämlik inkomstfördelning, nämligen kapitalinkomsterna. Tonvikten har i stället legat på en rad liberaliseringar

6. Exempel på sådana i grunden icke-politiska faktorer är kompetensdrivande teknologiska förändringar (Korpi \& Tåhlin 20II) och internets marknadsförstärkande effekter. 
som började införas på 1980-talet. Till dessa hör avregleringen av kreditmarknaden (1985), avskaffandet av de sista resterna av valutaregleringen (I989), de sänkta skatterna på kapitalinkomster (I99I) ${ }^{7}$ och förändringarna i de så kallade 3:I2-reglerna (2006), som gjorde det möjligt för småföretagare att redovisa en större del av aktieutdelningarna som inkomst av kapital i stället för som inkomst av tjänst, vilket gav dem kraftigt sänkt skatt. ${ }^{8}$ Ingen av de reformerna innebar någon märkbar förändring för vanliga löntagare och det fanns inte heller någon utbredd förståelse för dem när de infördes. ${ }^{9}$ De fick däremot stora konsekvenser för dem med de allra högsta inkomsterna, både genom att skapa förutsättningar för en utdragen värdepappersboom och genom att sänka skatten på kapitalvinster och utdelningar (Roine \& Waldenström 20I2).

Reformerna är alltså i mycket exempel på politik som bedrivs under radarn, där små men tydligt organiserade och skickliga grupper har kunnat driva igenom reformer som är av stor betydelse för dem själva, men knappt synliga ens för större organisationer, som fackföreningarna, och helt osynliga och obegripliga för den vanlige väljaren.

Parallellt med den stigande ojämlikheten har valdeltagandet sjunkit och klyftan mellan hög- och låginkomsttagare vidgats i detta avseende. I valet 1982, då ojämlikheten var som lägst, hamnade valdeltagandet på fantastiska 92 procent. I den översta decilen av inkomstfördelningen röstade nästan 95 procent av de röstberättigade. Men även i den lägsta

7. Den stora skattereformen I99I gav upphov till ett tudelat inkomstskattesystem, där kapitalinkomster beskattades proportionellt, medan arbetsinkomster fortfarande beskattades progressivt. I de högre inkomstklasserna skapade detta ett starkt incitament till inkomstväxling från arbets- till kapitalinkomster.

8. För en redogörelse för processen bakom kreditmarknadernas avreglering, se Svensson (1996). För en beskrivning av förändringarna i 3:I2-reglerna och deras rätt problematiska konsekvenser i termer av improduktiva inkomstskiften och skatteplanering, se Alstadsæter och Jacob (2012). Efter publiceringen av Alstadsæters och Jacobs rapport föreslog regeringen först långtgående begränsningar av möjligheten att skifta inkomster enligt 3:I2-reglerna, men man drog sedan tillbaka de flesta begränsningarna (antagligen efter framgångsrik lobbying från de påverkade företagen och personerna).

9. Ett talande exempel finner man i den ändring av 3:I2-reglerna som gjordes 2006, vilken är svår att förstå fullt ut även för en skolad iakttagare (som jag själv ...). Den gynnade ett fåtal personer, men gav stora ekonomiska fördelar för denna lilla grupp (Alstadsæter \& Jacob 20I2). 
decilen röstade över 90 procent $\mathrm{i}$ valet, vilket innebar att skillnaden $\mathrm{i}$ valdeltagande mellan den översta och nedersta decilen bara var drygt 4 procentenheter. I valet 2010 var valdeltagandet i den översta decilen fortfarande 95 procent, en andel som hållit sig relativt stabil mellan valen. Men i den nedersta decilen hade valdeltagandet sjunkit till mindre än 69 procent, vilket gav en skillnad på 27 procentenheter. Valdeltagandet $\mathrm{i}$ den lägsta decilen hade i princip sjunkit ända sedan 1982, med en särskilt stor nedgång mellan valen 1994 och 1998 (Oscarsson \& Holmberg 2013, tabell 3.2). ${ }^{\text {Io }}$

Orsakerna till det sjunkande valdeltagandet bland låginkomsttagare är komplexa, och bland förklaringarna bör beaktas en minskad identifiering med partierna, en ökad migration och andra faktorer. Det är dock svårt att inte slås av att skillnaderna i valdeltagande mellan olika inkomstgrupper vuxit så snabbt, och det är nära till hands att förklara denna utveckling med att de minst resursstarka känner sig svikna av politiken och politikerna (Oskarson 2007; Schäfer \& Streeck 2013).

Det verkar alltså som om Sverige är ännu ett exempel på hur stigande inkomst- och välståndsojämlikhet leder till ökade skillnader i politiskt deltagande och tillgång till politiska resurser (jfr Mettler \& Soss 2004; Jacobs \& Skocpol 2005). De fattigaste segmenten av befolkningen hamnar lätt utanför politiken, samtidigt som mer resursstarka grupper inte bara uppvisar samma höga valdeltagande som tidigare utan dessutom finner nya sätt och arenor att påverka politiken. Detta påverkar i sin tur den fördelningspolitik som förs - eller inte förs.

Eftersom denna utveckling till stor del följer den i många andra rika länder framstår Sverige ändå som ganska jämlikt (Gornick \& Jäntti 20I3). Och valdeltagandet är alltjämt på en nivå som USA bara kan drömma om. Det kan vara en orsak till att kopplingarna mellan det politiska deltagandet, de faktiska politiska besluten och de politiska kursändringarna, liksom de förändringar i inkomstfördelningen som blivit följden, ännu inte har fått den uppmärksamhet de förtjänar.

Io. De ökade skillnaderna i valdeltagande tonas märkligt nog ner i den senaste svenska valstudien (Oscarsson \& Holmberg 20I3, kap. 3). Detta ska kanske ses som ett tecken på att vi har fătt ett nytt "normaltillstånd", där villkor som skulle ha setts som upprörande för trettio år sedan nu mottas med en axelryckning. 


\section{Slutsats}

Vad de här förändringarna i Sverige sammantaget har gett oss är en annan form av politisk elitstyrning än de gamla korporativistiska strukturerna. Det är förstås viktigt att inte ha en romantisk föreställning om hur demokratiskt det korporativistiska Sverige var. Man ska komma ihåg att Sverige politiskt sett alltid har varit toppstyrt och experttungt (Steinmo 2003; 2013). Populismen har alltid varit ganska svag både på vänster- och högersidan, och starkt centraliserade organisationer och politiska partier spelade huvudrollen under hela den socialdemokratiska efterkrigstiden. Men detta var en lite annorlunda form av politisk elitstyrning än den vi ser i dag: den var fastare i formen, synligare och lite lättare att ställa till svars.

Dagens trend beskrivs ibland i termer av en ökad "pluralism", just för att den oligopolistiska organisationsstrukturen och de centrala överenskommelserna inom och utom staten luckrats upp och för att det tillkommit många nya politiska aktörer (till exempel Bäck \& Möller 2003, s. 196-204). Men som bör framgå av den här artikeln är en sådan beskrivning starkt vilseledande. Det vi har fått i stället är en otydlig, men alltjämt starkt elitstyrd process, där de ekonomiska resurserna har blivit ännu viktigare.

I artikeln har jag diskuterat några av följderna av den nya politiska ordningen, som den nya aktörsuppsättningen inom politiken, politikens minskade synlighet och förhållandet mellan ekonomisk och politisk makt, och den självförstärkande dynamiken mellan faktorer som ojämlikhet, deltagande, maktresurser och offentlig politik. I hög grad har jag beskrivit "det som sker i demokratier när ingen ser på" (Culpepper 20II, s. Xv) genom att lyfta fram några sidor av en ny, mycket ogenomskinlig, juridiskt orienterad och medieburen politisk maktordning och redogöra för några av denna ordnings viktigaste aktörer. Hittills har den nya maktordningen lett till en dramatiskt ökad ojämlikhet vad gäller inkomster, deltagande och möjligheter att påverka politiska beslut och resultat.

Den syn på "politiken som organiserad kamp" som jag valt för den här artikeln kanske några läsare uppfattar som märklig i ett svenskt politiskt och socialt sammanhang. Iakttagare av den svenska modellen har 
varit mer benägna att betona samarbetet, expertstyret och rationaliteten inom svensk politik och lyft fram modellen som ett exempel på "styrning som ingenjörsproblem" (Steinmo 2013). Men jag vill hävda att detta nog var en viss överdrift också under det organiserade klassamarbetets storhetstid (Korpi 1978), och att beskrivningen stämmer än mindre på dagens postkorporativistiska skugglandskap.

Detta ska förstås inte tolkas som att det har funnits någon storstilad plan eller ingåtts ljusskygga överenskommelser i syfte att göra svenskarnas inkomster och politiska deltagande mer ojämlika. Den ökade ojämlikheten är resultatet av många aktörers oberoende beslut för att på olika vis gynna sina egna. Jag låter också frågan stå öppen i vilken grad omfattningen av och metoderna för marknadernas avreglering har varit i huvudsak oundvikliga anpassningar till globala villkor eller i huvudsak resultatet av framgångsrik lobbying på uppdrag av dem som haft direkt intresse av att sådana reformer kom till stånd. Det sammanlagda resultatet har oavsett vilket varit växande och självförstärkande skillnader mellan olika gruppers möjligheter att påverka politiken och samhället.

Det är viktigt att här understryka att jag inte på något sätt antyder att Sverige skulle vara en mindre kopia av USA, eller att Sverige bara går

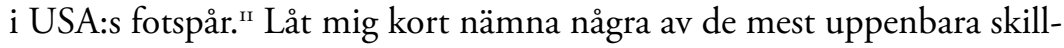
naderna: (a) de svenska medelinkomsttagarna har fått märkbart höjda realinkomster sedan mitten av 1990-talet, medan deras amerikanska motsvarighet knappt har höjt sina inkomster alls (Korpi \& Thålin 20II); (b) de organiserade aktörernas relativa maktmedel skiljer sig fortfarande mycket åt mellan de båda länderna, och det starkt ensidiga arbetsgivarledda angreppet på löner och anställningsvillkor i arbetsmarknadens nedre skikt har parerats mycket bättre i Sverige. Sammantaget bör för Sveriges del de omfördelande resultaten hellre beskrivas som att "vinnaren tar mest" än som i Hacker och Piersons boktitel att "vinnaren tar allt". Men det som är mest påfallande, i alla fall ur denna författares

II. Än mindre är artikeln ett försök att hävda att "Sverige är ett sämre samhälle än förr". Sverige år 20I5 är betydligt rikare, men mycket mer ojämlikt än landet var för några årtionden sedan. Det är ett mer tolerant och öppet samhälle, samtidigt som stora grupper inte är etablerade på arbetsmarknaden. Hur man bedömer utvecklingen beror på ens personliga och politiska värderingar och här väger samhällsvetenskapens bedömningar inte tyngre än lekmannens. 
perspektiv, är hur snabbt föredelningsresultaten och den organiserade politikens ramverk har förändrats i det som en gång var ett ytterst stabilt och socialdemokratiskt lett politiskt-organisatoriskt bygge.

Hur ser framtiden ut? Eftersom en mer detaljerad bild av den politiska makten i det postkorporativistiska Sverige ännu inte har tecknats skulle varje förutsägelse med nödvändighet bara kunna avse den närmaste framtiden och därmed bli ännu mer schablonartad och preliminär än artikeln i övrigt. De flesta politiska aktörer erkänner i dag den växande ojämlikheten som ett stort samhällsproblem. Detta kan tänkas skapa förväntningar om att det efter hand kommer att fattas politiska beslut ägnade att minska den ökande ojämlikheten. Jag anser emellertid att sådana förväntningar är tämligen ogrundade. Framtida regeringar kommer att vara bakbundna, dels av egna löften och åtaganden, dels av förändringarna i det institutionella landskapet.

Möjligheten att bedriva en omfördelande politik har kraftigt begränsats till följd av att ansvaret för politiken flyttats från folkvalda politiker till icke-valda expertorgan (till exempel den självständiga Riksbanken), som inte är särskilt intresserade av omfördelningspolitik, och till följd av att man infört mekanismer som reagerar automatiskt på omvärldsförändringar. ${ }^{\mathrm{I2}}$ Med tanke på att både det inhemska och det europeiska ekonomiska ramverket nu är inriktat på skuldminskning och fortsatt låg inflation snarare än att öka sysselsättningen, verkar det osannolikt att en ny regering skulle kunna slå in på en annan kurs mer än marginellt. Det lilla som finns kvar av självständigt politiskt beslutsfattande har kringskurits av partierna själva genom löften att i ganska liten utsträckning förändra företrädarnas linje. Utrymmet för politiska åtgärder i syfte att minska ojämlikheten är därför väldigt litet: politiken har inte mycket att sätta emot den kraftfulla ojämlikhetsskapande marknadsdynamiken.

I ett längre perspektiv är detta en oroväckande utveckling - man frågar sig hur demokratin ska kunna överleva dagens trender (jfr Crouch

I2. Den problematiska självsvåldiga utvidgningen av Riksbankens uppdrag till att omfatta en allmän korrigering av ekonomiska obalanser i stället för att enbart hålla inflationen i schack, liksom nödvändigheten att begränsa Riksbankens makt via förbättrade demokratiska kontrollmekanismer, diskuteras nu till och med av liberala kommentatorer och av före detta medlemmar av Riksbankens styrelse (Svensson 20I4; Wolodarski 20I4). 
20II; Streeck 2013). Om grupper som har missgynnats av marknadskrafternas logik känner att regeringsskiften inte längre leder till någon verklig förändring av politiken - att resultatet blir ungefär detsamma oavsett vem som sitter vid makten - är det inte så förvånande ifall de börjar tvivla på den representativa demokratin som idé. Och följderna märks tydligt, även i Sverige: sjunkande valdeltagande bland dem som har det sämst ställt, ökat stöd för den rasistiska extremhögern, växande oro i samhället. ${ }^{13}$ I kombination med de ökade möjligheterna för resursstarka aktörer att direkt påverka politiken på och utanför demokratins arena skapar detta problem för demokratin som den hittills har uppfattats.

Men de potentiellt postdemokratiska tendenserna i Europa behöver analyseras djupare innan de (eventuellt alarmistiska) slutsatserna kan bekräftas eller förkastas. Hur förändringar i politikens och politikskapandets processer är kopplade till politiska beslut eller icke-beslut som påverkar inkomstfördelningen är till stor del outforskat område här i Europa. För att komma tillbaka till Hacker och Pierson och avrunda artikeln vill jag understryka att deras bok är ett mycket viktigt bidrag till den forskningen och att den förhoppningsvis får efterföljare i en europeisk kontext. Europa skiljer sig på många punkter från USA, men som jag har försökt visa i artikeln äger flera av de argument som framförs i Hackers och Piersons bok giltighet också i ett europeiskt sammanhang och - kanske något överraskande - för svenska förhållanden.

\section{Översättning: Pär Svensson}

I3. Ett uppmärksammat exempel på det senare var kravallerna i maj 2013 i några fattiga Stockholmsförorter, vilka utlöstes av att polisen sköt ihjäl en man i Husby. Även om bakgrunden till dylika upplopp alltid är komplexa (och även inbegriper planerade manövrar av rabiata bråkmakare) och upploppen inte kan förklaras med en enda orsak, är det inte svårt att se dem som delvis kopplade till en ökande social frustration till följd av växande ojämlikhet och försämrade möjligheter till arbete. 


\section{Referenser}

Alstadsæter, Annette \& Jacob, Martin (2012) Income Shifting in Sweden. An Empirical Evaluation of the 3:I2 Rules. Stockholm: Finansdepartementet.

Bengtsson, Håkan A. (2013) "Vad gör dom på Timbro efter tre?", i Dagens Arena, I2 januari.

URL: http://www.dagensarena.se/opinion/vad-gor-dom-pa-timbro-efter-tre/ (I2 december 20I4)

Bergh, Andreas \& Erlingsson, Gissur Ó. (2009) "Liberalization without Retrenchment: Understanding the Consensus on Swedish Welfare State Reforms", i Scandinavian Political Studies, 32, I, s. 7I-93.

DoI: http://dx.doi.org/IO.IIII/j.I467-9477.2008.002IO.x

Björklund, Anders \& Jäntti, Markus (20II) Inkomstfördelningen i Sverige. Stockholm: SNS.

Björklund, Anders \& Jäntti, Markus (2013) "Country Case Study - Sweden”, i Jenkins, Stephen P. m.fl. (red.) The Great Recession and the Distribution of Household Income. Oxford: Oxford University Press.

Blomqvist, Paula (2004) "The Choice Revolution. Privatization of Swedish Welfare Services in the I990", i Social Policy \& Administration, 38, 2, s. 139-155. DOI: http://dx.doi.org/IO.IIII/j.I467-9515.2004.00382.x

Blyth, Mark \& Katz, Richard S. (2005) "From Catch-all Politics to Cartelisation: The Political Economy of the Cartel Party", i West European Politics, 28, I, s. 33-6o. DOI: http://dx.doi.org/Io.I080/OI40238042000297080

Boréus, Kristina (1994) Högervåg. Nyliberalism och kampen om språket $i$ svensk offentlig debatt 1969-1989. Stockholm: Tiden.

Burley, Anne-Marie \& Mattli, Walter (1993) "Europe Before the Court: A Political Theory of Legal Integration", i International Organization, 47, I, s. 4I-76.

DOI: http://dx.doi.org/Io.IOI7/Soo20818300004707

Bäck, Mats \& Möller, Tommy (2003) Partier och organisationer. 6:e uppl. Stockholm: Norstedts juridik.

Crouch, Colin (20II) Postdemokrati. Göteborg: Daidalos.

Culpepper, Pepper D. (20II) Quiet Politics and Business Power. Corporate Control in Europe and Japan. Cambridge: Cambridge University Press.

Ekström, Mats \& Tolson, Andrew (red.) (2013) Media Talk and Political Elections in Europe and America. Basingstoke: Palgrave.

Esser, Frank (2013) "Mediatization as a Challenge: Media Logic versus Political Logic", i Kriesi, Hanspeter m.fl., Democracy in the Age of Globalization and Mediatization. New York: Palgrave Macmillan.

Fulcher, James (1991) Labour Movements, Employers and the State. Conflict and Co-operation in Britain and Sweden. Oxford: Clarendon Press.

Garsten, Christina; Rothstein, Bo \& Svallfors, Stefan [kommande] Makt utan mandat. De policyprofessionella $i$ svensk politik. Bokmanus under arbete, väntas utkomma i april 2015 . 
Gingrich, Jane (20II) Making Markets in the Welfare State. The Politics of Varying Market Reforms. Cambridge: Cambridge University Press.

Gornick, Janet \& Jäntti, Markus (2013) "Introduction”, i Gornick, Janet \& Jäntti, Markus (red.) Income Inequality. Economic Disparities and the Middle Class in Affluent Countries. Stanford: Stanford University Press.

Hacker, Jacob \& Pierson, Paul (20IO) Winner-take-all Politics. New York: Simon \& Schuster.

Hartman, Laura (red.) (20II) Konkurrensens konsekvenser. Vad händer med svensk välfärd? Stockholm: SNS.

Heclo, Hugh (1978) "Issue Networks and the Political Establishment", i King, Anthony (red.) The New American Political System. Washington: American Enterprise Institute.

Hermansson, Jörgen m.fl. (1999) Avkorporativisering och lobbyism. Konturerna till en ny politisk modell. Stockholm: Fakta info direkt. SOU I999:I2I.

Höpner, Martin \& Schäfer, Armin (2012) "Embeddedness and Regional Integration: Waiting for Polanyi in a Hayekian Setting", i International Organization, 66, 3, s. $429-455$. DoI: http://dx.doi.org/I0.I0I7/Soo2081831200015X

Jacobs, Lawrence R. \& Skocpol, Theda (2005) Inequality and American Democracy. New York: Russell Sage.

Jordahl, Henrik (red.) (2013) Välfärdstjänster i privat regi. Framväxt och drivkrafter. Stockholm: SNS.

Kjellberg, Anders (20IIa) "Trade Unions and Collective Agreements in a Changing World”, i Thörnquist, Anette \& Engstrand, Åsa-Karin (red.) Precarious Employment in Perspective. Old and New Challenges to Working Conditions in Sweden. Bryssel: Peter Lang.

Kjellberg, Anders (20I1b) "The Decline in Swedish Union Density since 2007", i Nordic Journal of Working Life Studies, I, I, s. 67-93.

URL: http://rossy.ruc.dk/ojs/index.php/njwls/article/view/2336 (I2 december 20I4)

Korpi, Walter (1978) The Working Class in Welfare Capitalism. Work, Unions and Politics in Sweden. London: Routledge \& Kegan Paul.

Korpi, Tomas \& Tåhlin, Michael (20II) "Changing Work-Life Inequality in Sweden: Globalization and other Causes", i Blossfeld, Hans-Peter m.fl. (red.) Globalized Labour Markets and Social Inequality in Europe. Basingstoke: Palgrave Macmillan.

Kumlin, Staffan (2009) "Blaming Europe? Exploring the Variable Impact of National Public Service Dissatisfaction on EU Trust", i Journal of European Social Policy, I9, 5, s. 408-420. DoI: http://dx.doi.org/Io.1177/0958928709344248

Lewin, Leif \& Lindvall, Johannes [kommande] "One Hundred Years of Swedish Economic Policy", i Pierre, Jon (red.) The Oxford Handbook of Swedish Politics. Oxford: Oxford University Press.

Lindbom, Anders [kommande] "The Importance of Policy Feedback. The Swedish Welfare State After Eight Years of Centre-Right Government", i Pierre, Jon (red.) The Oxford Handbook of Swedish Politics. Oxford: Oxford University Press. 
Lindvall, Johannes \& Rothstein, Bo (2006) "Sweden: The Fall of the Strong State", i Scandinavian Political Studies, 29, I, s. 47-63. DoI: http://dx.doi.org/IO.IIII/j.I467-9477.2006.00I4I.x

Lindvall, Johannes \& Sebring, Joakim (2005) "Policy Reform and the Decline of Corporatism in Sweden", i West European Politics, 28, 5, s. I057-I074. DoI: http://dx.doi.org/Io.IO80/0I4023805003II8I4

Lundberg, Urban (2003) Juvelen i kronan. Socialdemokraterna och den allmänna pensionen. Stockholm: Hjalmarson \& Högberg.

Lundberg, Urban (2009) "The Democratic Deficit of Pension Reform: The Case of Sweden”, i Petersen, Jørn Henrik \& Petersen, Klaus (red.) The Politics of Age. Frankfurt am Main: Peter Lang.

Mair, Peter (2008) "The Challenge to Party Government", i West European Politics, 3I, I-2, s. 2II-234. DOI: http://dx.doi.org/IO.IO80/OI402380701835033

Maktutredningen (1990) Demokrati och makt i Sverige. Maktutredningens huvudrapport. Stockholm: Allmänna förlaget. SOU i990:44.

Mettler, Suzanne \& Soss, Joe (2004) "The Consequences of Public Policy for Democratic Citizenship: Bridging Policy Studies and Mass Politics", i Perspectives on Politics, 2, I, s. 55-73. DoI: http://dx.doi.org/IO.IOI7/SI537592704000623

Naurin, Daniel (2007) Deliberation Behind Closed Doors. Transparency and Lobbying in the European Union. Colchester: ECPR Press.

Nilsson, Lennart (20I3) "Välfärdspolitik och välfärdsopinion 1986-20I2: Vinster i välfärden?”, i Weibull, Lennart; Oscarsson, Henrik \& Bergström, Annika (red.) Vägskäl. Göteborg: SOM-institutet.

Nilsson, Tommy (1985) Frän kamratföreningar till facklig rörelse. De svenska tjänstemännens organisationsutveckling I900-1980. Lund: Arkiv förlag.

Nycander, Svante (20I3) "Svenskt Näringslivs politiska insatser skadar politiken", i Dagens Nyheter, 7 januari.

URL: http://www.dn.se/debatt/svenskt-naringslivs-politiska-insatser-skadarpolitiken/ (I2 december 20I4)

OECD (20II) Divided We Stand. Why Inequality Keeps Rising. Paris: OECD. DoI: http://dx.doi.org/IO.I787/9789264II9536-en

Olofsson, Gunnar (1995) Klass, rörelse, socialdemokrati. Essäer om arbetarrörelsens sociologi. Lund: Arkiv förlag.

Oscarsson, Henrik \& Holmberg, Sören (2013) Nya svenska väljare. Stockholm: Norstedts juridik.

Oskarson, Maria (2007) "Social Risk, Policy Dissatisfaction, and Political Alienation: A Comparison of Six European Countries", i Svallfors, Stefan (red.) The Political Sociology of the Welfare State. Institutions, Social Cleavages, and Orientations. Stanford: Stanford University Press.

Persson, Mikael; Wass, Hanna \& Oscarsson, Henrik (2013) "The Generational Effect in Turnout in the Swedish General Elections, 1960-2010", i Scandinavian Political 
Studies, 36, 3, s. 249-269.

DoI: http://dx.doi.org/IO.IIII/I467-9477.12005

Roine, Jesper \& Waldenström, Daniel (20I2) "On the Role of Capital Gains in Swedish Income Inequality", i Review of Income and Wealth, 58, 3, s. 569-587. DOI: http://dx.doi.org/IO.IIII/j.I475-499I.20II.00475.x

Scharpf, Fritz W. (20I0) "The Asymmetry of European Integration, or Why the EU cannot be a 'Social Market Economy', i Socio-Economic Review, 8, 2, s. 2II-250. DoI: http://dx.doi.org/Io.Io93/ser/mwpo3I

Schmidt, Vivien A. (2013) "Democracy and Legitimacy in the European Union Revisited: Input, Output and 'Throughput', i Political Studies, 6I, I, s. 2-22. DoI: http://dx.doi.org/IO.IIII/j.I467-9248.2012.00962.x

Schäfer, Armin \& Streeck, Wolfgang (2013) "Introduction: Politics in the Age of Austerity", i Schäfer, Armin \& Streeck, Wolfgang (red.) Politics in the Age of Austerity. Cambridge: Polity Press.

Steinmo, Sven (2003) "Bucking the Trend? The Welfare State and the Global Economy: The Swedish Case Up Close", i New Political Economy, 8, I, s. 3I-48. DOI: http://dx.doi.org/I0.I080/13563460320000787I4

Steinmo, Sven (2010) The Evolution of Modern States. Sweden, Japan, and the United States. Cambridge: Cambridge University Press.

Steinmo, Sven (2013) "Governing as an Engineering Problem: The Political Economy of Swedish Success", i Schäfer, Armin \& Streeck, Wolfgang (red.) Politics in the Age of Austerity. Cambridge: Polity Press.

Streeck, Wolfgang (2013) Köpt tid. Den demokratiska kapitalismens uppskjutna kris. Göteborg: Daidalos.

Strömbäck, Jesper (2008) "Four Phases of Mediatization: An Analysis of the Mediatization of Politics", i International Journal of Press/Politics, 13, 3, s. 228-246.

Dor: http://dx.doi.org/I0.1177/1940161208319097

Svallfors, Stefan (2000) Sidospår. Essäer om klass \& politik. Umeå: Boréa.

Svallfors, Stefan (20II) "A Bedrock of Support? Trends in Welfare State Attitudes in Sweden, I98I-20I0", i Social Policy \& Administration, 45, 7, s. 806-825.

DOI: http://dx.doi.org/IO.IIII/j.I467-95I5.20II.00796.x

Svensson, Lars E. O. (20I4) "Skärp den demokratiska kontrollen av Riksbanken", i Dagens Nyheter, 28 maj.

URL: http://www.dn.se/debatt/skarp-den-demokratiska-kontrollen-av-riksbanken/ (I2 december 2014)

Svensson, Torsten (1996) Novemberrevolutionen. Om rationalitet och makt $i$ beslutet att avreglera kreditmarknaden 1985. Stockholm: Fritzes. Ds 1996:37.

Togeby, Lise m.fl. (2003) Magt og demokrati i Danmark. Hovedresultater fra Magtudredningen. Århus: Aarhus universitetsforlag.

Uvell, Markus (2013) "Centerns enda chans är att vända hemåt", i Expressen, 27 augusti. URL: http://www.expressen.se/debatt/centerns-enda-chans-ar-att-vanda-hemat/ (I2 december 20I4)

van Biezen, Ingrid; Mair, Peter \& Poguntke, Thomas (20I2) "Going, Going, ... Gone? The Decline of Party Membership in Contemporary Europe", i European Journal of 
ARKIV | NR 3

Political Research, 5I, I, s. 24-56.

Dor: http://dx.doi.org/Io.IIII/j.I475-6765.2011.0I995.x

Weaver, R. Kent (I986) "The Politics of Blame Avoidance", i Journal of Public Policy, 6, 4, s. 37I-398.

DOI: http://dx.doi.org/Io.IOI7/SoI438I4Xoooo42I9

Wolodarski, Peter (20I4) "Ta tillbaka makten över Riksbanken”, i Dagens Nyheter, I5 juni.

URL: http://www.dn.se/ledare/signerat/peter-wolodarski-ta-tillbaka-makten-overriksbanken/ (I2 december 20I4)

Öberg, Tommy (20I4) "Riskkapitalister sökte stöd från LO”, i Arbetet, 2I februari. URL: http://arbetet.se/2014/O2/2I/riskkapitalet-sokte-stod-fran-lo/ (I2 december 20I4)

Østerud, Øyvind; Engelstad, Fredrik \& Selle, Per (2003) Makten og demokratiet. En sluttbok fra Makt-og demokratiutredningen. Oslo: Gyldendal. 
Klassiska avhandlingar från Arkiv förlag

\section{Stefan Svallfors}

Vem älskar välfärdsstaten?

Attityder, organiserade intressen och svensk välfärdspolitik

Som följd av den ekonomiska krisen på 1970-talet blev den svenska välfärdsstaten utsatt för så stark kritik att många talade om en förändring i själva det politiska debattklimatet. Av denna undersökning framgår dock att den offentliga sektorn fortfarande har starkt stöd, särskilt inom arbetarklassen, men även långt in i borgerligheten.

1989, mjukband, 225 sidor

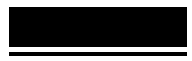

\section{Sune Sunesson}

\section{Politik och organisation}

Staten och arbetarklassens organisationer

Med utgångspunkt från den historiska materialismen kritiserar författaren den förhärskande statsvetenskapens och sociologins begrepp. Bokens centrala tema är en analys av de processer, som återskapar och vidmakthåller organisatoriska och ideologiska förhållanden. I synnerhet uppmärksammas den kapitalistiska statens roll som avgörande faktor för organisationers utveckling.

1974, mjukband, 206 sidor

»Böckerna går att beställa i bokhandeln och från www.arkiv.nu« 


\section{Moderna klassiker}

\section{Marie Jahoda}

\section{Paul F. Lazarsfeld, Hans Zeisel De arbetslösa i Marienthal}

\section{Arkiv förlag}

De arbetslösa $i$ Marienthal (Die Arbeitslosen von Marienthal) från I933 av Marie Jahoda, Paul F. Lazarsfeld och Hans Zeisel är ett av samhällsvetenskapens mest legendariska arbeten. $\mathrm{Nu}$ finns den för första gången på svenska. Marienthalstudien lade grunden till mycket av dagens arbetslöshetsforskning och var banbrytande i sitt sätt att kombinera kvalitativa och kvantitativa data på ett sätt som fortfarande inspirerar. En inledning av den österrikiske sociologen Christian Fleck och ett efterord av den svenske sociologen Paavo Bergman presenterar verket och dess betydelse för samhällsvetenskapen.

Översättning Svenja Hums Arkiv förlag 20I4, I90 sidor 